\title{
Freeze-drying as an alternative method of human sclera preservation
}

\author{
Liofilização como alternativa à preservação de esclera humana
}

\author{
Ana Carolina de Arantes Frota ${ }^{1}$ \\ Acácio Alves de Souza Lima Filho² \\ Ana Beatriz Toledo Dias ${ }^{3}$ \\ Andréia Cristina dos Santos Lourenço ${ }^{4}$ \\ Emilia Antecka ${ }^{5}$ \\ Miguel N. Burnier Jr. ${ }^{6}$
}

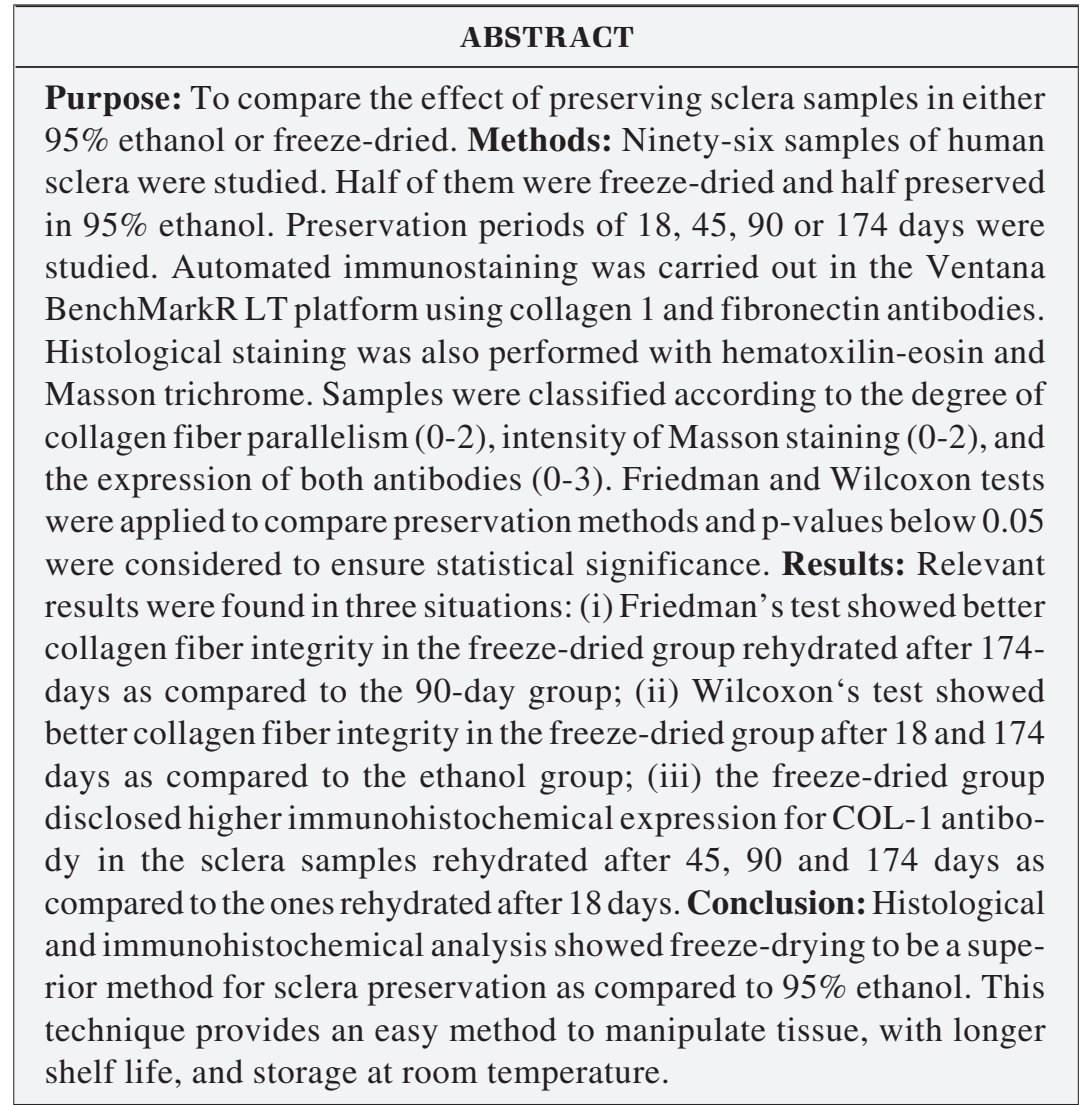

Keywords: Freeze-drying/methods; Sclera; Tissue preservation; Dose-response relationship, drug; Ethanol; Immunohistochemistry; Collagen

\section{INTRODUCTION}

Human graft techniques are commonly employed today to manage ocular diseases that compromise the tectonic stability of the eye, and also to patch in ocular surgery ${ }^{(1)}$.

Sclera grafts have been recently used for sclera perforation repair ${ }^{(2)}$, hypotony treatment due to leaking and overfiltrating blebs ${ }^{(3-4)}$, scleromala$\mathrm{cia}^{(5)}$, eyelid reconstruction ${ }^{(6)}$ and exposed hydroxyapatite orbital implants ${ }^{(7)}$.

Reinforcement of thin or perforated sclera is necessary to prevent prolapse of ocular contents and secondary infection, especially in the occurrence of choroidal exposure. Although many other tissues and synthetic materials have been added to the ever expanding list of reconstructive materials, no material has been universally agreed upon its absolute efficiency. 
Long listed reports of success on the use of sclera grafts are available today. Many are the advantages of the use of sclera tissue, the readiness and endurance to preservation, the structural strengh, the flexibility, and malleability being reported among the most relevant. Furthermore, the sclera has a desirable capability to neatly blend in with the host sclera to its natural curvature, and causes little or no inflammatory reaction ${ }^{(1)}$.

Sclera homografts, the most commonly used form of sclera patch, may be stored in three different ways ${ }^{(8)}$ :

\section{Freezing}

The tissue is frozen $\left(-20^{\circ} \mathrm{C}\right)$ in an antibiotic solution to be used until 3 months after the preservation date. Thawing should take place at room temperature after which the material should be kept refrigerated at $2-6^{\circ} \mathrm{C}$ for utilization. It should never undergo refreezing and its storage time limit, once unfrozen, should never exceed 24 hours $^{(8)}$.

\section{Ethanol fixation}

The tissue is preserved in ethanol concentrations above $70 \%$ at room temperature, being expected to maintain up to 5day full validity. Before utilization the tissue should be washed in a balanced salt solution containing antibiotics ${ }^{(8)}$.

\section{Dehydration}

- Glycerin dehydration. Tissue may be stored at room temperature for future surgical application up to 3 months after the date of preservation. Surgical utilization requires hydration, a process consisting of 15 to 30 minutes immersion of the tissue in a balanced salt solution to which antibiotics have been previously added ${ }^{(8)}$.

- Acetone. Tutoplast ${ }^{\circledR}$ (Tutogen Medical Inc., Alachua, FL, U.S.A) is a patented, scientific and technology-based process of viral inactivation, preservation and sterilization of human tissue for transplantation. The tissue, dehydrated in acetone, is biologically and mechanically stable, is immunologically safe and can be stored at room temperature up to 5 years.

- Freeze-drying is an alternative method for human tissue preservation consisting of rapid freezing followed by dehydration of the material under high pressure. The final product results in a biologically stable material with higher feasibility to stand longer storage periods at room temperature as compared to other ordinary methods of tissue preservation ${ }^{(9)}$.

Freeze-drying as an industrial process came about World War II, a time when the increasingly high demand for human blood plasma reached critical levels ${ }^{(10)}$.

The great many advantages the freeze-drying technique brought to the clinical practice are well known today, namely the decrease of both surgical time and surgical morbidity, the assessment of the graft size and shape prior to surgical procedures and the possibility to have tissue graft storage in operating rooms ${ }^{(9)}$. This alternative technique has been used to preserve many biological products such as bovine pericardium ${ }^{(9,11)}$, human red blood cells ${ }^{(12)}$, epidermal keratinocytes ${ }^{(13)}$, amniotic membrane $^{(14)}$ vaccines $^{(15)}$ and others.
Reviews on freeze-dried sclera are scarce. In 1965 some authors first advertised the benefits of freeze-drying sclera tissue $^{(16)}$. The use of lyophilized sclera grafts to correct preprosthetic alveolar ridge defects were found to statistically improve the grafted sites ${ }^{(17)}$. Other authors also used freeze-dried human sclera grafts in periodontal ${ }^{(18)}$ and retinal detachment surgery ${ }^{(19)}$.

The purpose of this study was to evaluate the efficiency of two different methods of sclera preservation, freeze-drying and $95 \%$ ethanol. To the best of our knowledge, this study can be said as pioneering in the attempt to map histological and immunohistochemical characteristics of sclera tissue undergoing preservation by freeze-drying and $95 \%$ alcohol.

\section{METHODS}

This was a comparative, prospective study. Six donor scleras were collected at the Eye Bank of the Brazilian Ophthalmology Society of Rio de Janeiro, Brazil. An informed consent was obtained allowing the use of human tissue for research by the eye Bank. All donors had negative serologic tests for hepatitis B and C virus, syphilis and human immunodeficiency virus. After the donation the sclera samples were first preserved in $95 \%$ alcohol.

Each sclera was half-divided as a means to expose equal sclera portions to two different preservation techniques - 95\% ethanol preservation (group E) and freeze-drying (group F). Subsequently, each half was then divided into 8 pieces, so it would be possible to have two samples from each studied sclera after 4 different periods of preservation - 18 days, 45 days, 90 days and 174 days.

\section{Freeze-drying process}

The freeze-dried specimens were cryopreserved in a $2.3 \mathrm{M}$ sucrose solution ${ }^{(20)}$ and then submersed at $-114^{\circ} \mathrm{C}$ in a mixture of dry ice and isopropyl ethanol. The dehydration was performed in a $\mathrm{Boc}^{\circledR}$ equipment, model ModulyoD, at a temperature of $-45^{\circ} \mathrm{C}$. The freeze-drying cycle totalled 24 hours.

\section{Tissue processing}

After 18, 45, 90 and 174 days/period, two samples from groups $\mathrm{E}$ and $\mathrm{F}$ were formalin-fixed and paraffin-embedded. Hematoxilin \& eosin (HE) and Masson trichrome (MT) staining were performed for histological assessment. Also immunohistochemistry for anti-collagen 1 (COL-1) and anti-fibronectin (NCL-FIB) monoclonal antibodies was performed. Samples were classified in accordance with the degree of collagen fiber parallelism (0-2), intensity of Masson staining (0-2), and the expression of COL-1 and NCL-FIB antibodies (0-3).

The classification was established based on the characteristics of a fresh enucleated sclera, directly fixed in $10 \%$ formalin, also stained by HE, MT and treated for COL- 1 and NCL-FIB antibody expression (0-3).

All samples were analyzed and classified by two qualified pathologists. 


\section{Automated staining}

In the Ventana BenchMark, the pathways COL-1 and NCLFIB, staining module were used according to the protocol and instructions provided by Ventana Medical System Inc. Arizona. The fully automated processing of bar code labeled slides included baking of the slides, solvent free deparaffinization, and enzymatic antigen retrieval for COL-1 and FIB, during 4 min with protease 1 . Incubation with monoclonal mouse anti-COL-1 (Abcam, Cambridge, MA) and anti-fibronectin (Novocastra ${ }^{\mathrm{TM}}$ Laboratories Ltd, UK) antibodies, both diluted 1:200, was performed for $30 \mathrm{~min}$ at $37^{\circ} \mathrm{C}$. The next step was application of biotinylated secondary antibody $(8 \mathrm{~min}$, $37^{\circ} \mathrm{C}$ ) followed by an avidin/streptavidin enzyme conjugate complex $\left(8 \mathrm{~min}, 37^{\circ} \mathrm{C}\right)$, and further detection by Fast Red chromogenic substrate contrastained with hematoxylin. As a positive control, sections of tonsil were used for collagen 1 and renal tissue for fibronectin. For negative controls the primary antibodies were omitted.

The following (Tables 1, 2 and 3) illustrate the criteria applied to the classification of the samples.

\section{Statistical methods}

The mean scores of each feature were compared between each preservation method and each sclera using Friedman and Wilcoxon's tests. Separate analysis was carried out for

Table 1. Scores applied for hematoxilin-eosin staining

\begin{tabular}{l|cl} 
H\&E staining & Score & Characteristics \\
Collagen fibers & 0 & Strong waveness \\
parallelism & 1 & Weak waveness \\
& 2 & Parallel fibers \\
\hline
\end{tabular}

Table 2. Scores applied for Masson trichrome staining

\begin{tabular}{|l|cl|}
\hline TM staining & Score & \multicolumn{1}{c|}{ Characteristics } \\
$\begin{array}{l}\text { Collagen fibers } \\
\text { integrity }\end{array}$ & 0 & $\begin{array}{l}\text { Presence of badly } \\
\text { preserved fibers } \\
100 \% \text { preserved fibers }\end{array}$ \\
\hline
\end{tabular}

\begin{tabular}{|c|c|c|}
\hline $\begin{array}{l}\text { IHQ expression of } \\
\text { antibodies }\end{array}$ & Score & Characteristics \\
\hline \multirow{4}{*}{ COL-1 and FIB } & 0 & $\begin{array}{l}\text { Fibers/cells negative for the } \\
\text { marker }\end{array}$ \\
\hline & 1 & $\begin{array}{l}\text { Less than } 50 \% \text { of fibers/cells } \\
\text { positive for the marker }\end{array}$ \\
\hline & 2 & $\begin{array}{l}50 \%-75 \% \text { of fibers/cells } \\
\text { positive for the marker }\end{array}$ \\
\hline & 3 & $\begin{array}{l}\text { More than } 75 \% \text { of fibers/cells } \\
\text { positive for the marker }\end{array}$ \\
\hline
\end{tabular}

each sclera group, considering a p-value of less than 0.05 to ensure statistical significance. All calculations were computer-based (SPSS 11.5; SPSS Inc., Chicago, Illinois, USA) and all data accumulation was in accordance with Country and Provincial laws and the tenets of the Declaration of Helsinki.

\section{RESULTS}

\section{COL-1 immunohistochemistry}

Automated staining with the COL-1 antibody in the BenchMark yielded a consistent staining pattern for the ethanol-preserved samples in all different studied periods, when analyzed by Friedman's test $\left(\chi^{2}\right.$ calc $\left.=3.750 \mathrm{p}=0.290\right)$. The freeze-dried group disclosed stronger COL-1 expression after 45, 90 and 174 days of preservation when compared to 18 days $\left(\chi^{2}\right.$ calc $\left.=12.000 \mathrm{p}=0.007\right)$. Wilcoxon's test was performed to compare the immunohistochemical expression of COL- 1 in both preservation methods, considering each studied period. No statistical difference was observed among the four analyzed periods (18 days: $\mathrm{z}$ calc $=-1.134$ $\mathrm{p}=0.257 ; 45$ days: $\mathrm{z}$ calc $=0.000 \mathrm{p}=1.000 ; 90$ days: $\mathrm{z}$ calc $=-1.414$ $\mathrm{p}=0.157 ; 174$ days: $\mathrm{z}$ calc $=-1.000 \mathrm{p}=0.317)$.

\section{FIB immunohistochemistry}

Friedman's test did not detect any variability along the studied period either in the immunohistochemical expression of ethanol $\left(\chi^{2}\right.$ calc $\left.=7.714 \mathrm{p}=0.052\right)$ or the freeze-dried sclera samples $\left(\chi^{2}\right.$ calc $\left.=3.000 \mathrm{p}=0.392\right)$. Wilcoxon's test was performed to compare the outcomes of each preservation method within a specific period of time. Results revealed no statistical difference between ethanol and freeze-dried samples analyzed after $18(\mathrm{z}$ calc $=0.000 \mathrm{p}=1.000), 45(\mathrm{z}$ calc $=0.000$ $\mathrm{p}=1.000), 90(\mathrm{z}$ calc $=0.000 \mathrm{p}=1.000)$ and 174 days of preservation $(\mathrm{z}$ calc $=-1.633 \mathrm{p}=0.102)$.

\section{HE staining}

HE staining was employed to analyze the collagen fiber architecture (parallelism) of ethanol and freeze-dried sclera samples after 18, 45, 90 and 174 days of preservation. Friedman's test did not show any statistical differences by both studied methods (ethanol: $\chi^{2}$ calc $=7.462 \mathrm{p}=0.059$; freezedried: $\chi^{2}$ calc $\left.=0.333 \mathrm{p}=0.954\right)$. Wilcoxon 's test was performed to compare the collagen fiber architecture in both preservation methods, considering each particular studied period. No statistical difference was observed among the four analyzed periods $(18$ days: $\mathrm{z}$ calc $=-0.378 \mathrm{p}=0.705 ; 45$ days: $\mathrm{z}$ calc $=-0.577 \mathrm{p}=0.564 ; 90$ days: $\mathrm{z}$ calc $=-1.633 \mathrm{p}=0.102$; 174 days: $\mathrm{z}$ calc $=-1.414 \mathrm{p}=0.157)$.

\section{MT staining}

MT staining was performed to analyze the structure of the collagen fibers (integrity) from sclera samples by observation 
of the intensity of Masson staining. Friedman's test did not detect any statistical differences in the ethanol preserved samples within 174 days/period $\left(\chi^{2}\right.$ calc $\left.=6.000 p=0.112\right)$. However, the freeze-dried samples disclosed better preservation of the collagen fibers after 174 days/period as compared to 90 days/period ( $\chi^{2}$ calc $\left.=13.000 \mathrm{p}=0.005\right)$. Wilcoxon's test was performed to compare the collagen fiber structure in both preservation methods considering each studied period. A statistical difference was observed between both preservation methods, the freeze-dried samples being better preserved after 18 and 174 days of preservation (18 days: $\mathrm{z}$ calc $=-2.000$ $\mathrm{p}=0.046 ; 45$ days: $\mathrm{z}$ calc $=-1.000 \mathrm{p}=0.317 ; 90$ days: $\mathrm{z}$ calc $=-1.732$ $\mathrm{p}=0.083 ; 174$ days: $\mathrm{z}$ calc $=-2.236 \mathrm{p}=0.025$ ).

\section{DISCUSSION}

The aim of this study was to compare the histological and morphological characteristics of sclera grafts preserved by two different techniques: 95\% ethanol and freeze-drying. Results indicate that freeze-dried sclera specimens reacted better than those preserved by $95 \%$ ethanol, thus disclosing freezedrying technique as a safe alternative method of sclera tissue preservation.

The most ordinary methods of sclera preservation are ethanol or glycerin, widely used in ophthalmology surgeries ${ }^{(3-4,6)}$.

Literature concerning freeze-dried sclera is scarce. There are few articles published on this issue, yet the use of dehydrated sclera grafts in ophthalmic surgeries showed to be successful ${ }^{(17-19)}$. However there is no study analyzing the effects of this technique on the tissue's structure.

We aimed to evaluate the possibility of freeze-drying sclera grafts, because of the advantages offered by this method. Freeze-dried sclera tissue is more convenient for routine use than ethanol-preserved grafts, being more readily available; they can be transported and stored at room temperature and they are ready for use at any time.

According to our knowledge, no study comparing the histological and morphological characteristics of ethanol and freeze-dried sclera grafts has been previously reported.

Proven advantages of freeze-dried tissue geared our research into evaluating the feasibility of applying this technique also to sclera grafts, such as higher convenience during routine procedures than that of its counterparts ethanol and glycerin preserved grafts; readiness to use, easy transportation and room-storage capability. Also the handicaps of ethanol and glycerin grafts as compared to freeze-dried ones are incomparable grater if important determinating factors shall be considered, such as a full dependence on organ donation and an imperative necessity of storage in banks. Moreover, sclera patches preserved by freeze-drying have much more extended expiring dates when compared to those with other preservation methods.

The properties of freeze-dried sclera turn them into an excellent material for surgery: handiness after rehydration with physiologic saline, easiness to cut and give any desired shape or size; and inertness, which reduces any inflammatory reaction ${ }^{(19)}$.

\section{CONCLUSION}

The results of our study indicate that freeze-dried sclera grafts are well-preserved when compared to $95 \%$ ethanolpreserved ones, and can be an alternative material for use in ophthalmologic surgeries. This technique provides an easy to manipulate tissue, with long shelf life, and storage at room temperature.

\section{RESUMO}

Objetivo: Comparar dois métodos de preservação de esclera humana, liofilização e álcool 95\%, em diferentes períodos de tempo. Métodos: Foram avaliados 96 fragmentos de seis escleras humanas. Metade das amostras foi submetida ao processo de liofilização e metade conservada em álcool 95\%. Dois fragmentos de cada grupo foram avaliados pelas colorações de hematoxilina-eosina e tricrômio de Masson e submetidos a técnica de imuno-histoquímica para os anticorpos fibronectina e colágeno 1, após 18, 45, 90 e 174 dias de preservação. Os espécimens foram classificados de acordo com o paralelismo (PF:0-2) e integridade (IF:0-1) das fibras de colágeno e expressão imuno-histoquímica para os anticorpos fibronectina (FIB:0-3) e colágeno 1 (COL1:0-3). A análise estatística foi realizada por meio dos testes de Friedman e Wilcoxon e o valor de p menor que 0,05 foi considerado estatisticamente significante. Resultados: Verificaram-se diferenças significantes em três situações: (i) maior integridade das fibras de colágeno das escleras liofilizadas após 174 dias quando comparado aos 90 dias; (ii) maior expressão imuno-histoquímica para o anticorpo COL-1 nas amostras de escleras liofilizadas após os 18 dias iniciais de preservação; (iii) maior integridade das fibras de colágeno das escleras liofilizadas após 18 e 174 dias quando comparado às escleras preservadas em álcool. Conclusões: A preservação de tecido escleral por liofilização mostrou-se técnica tão eficaz quanto a preservação em álcool, apresentado vantagem quando considerada a integridade das fibras de colágeno. A liofilização mostra-se benéfica por permitir a estocagem do tecido em temperatura ambiente e com prazo de validade estendido.

Descritores: Liofilização/metodos; Esclera; Preservação de tecido; Relação dose-resposta a droga; Etanol; Imunoistoquímica; Colágeno

\section{REFERENCES}

1. Sangwan VS, Jain V, Gupta P. Structural and functional outcome of scleral patch graft. Eye. 2007;21(7):930-5.

2. Rodriguez-Ares MT, Tourino R, Capeans C, Sanchez-Salorio M. Repair of scleral perforation with preserved scleral and amniotic membrane in Marfan's syndrome. Ophthalmic Surg Lasers. 1999;30(6):485-7.

3. Harizman N, Ben-Cnaan R, Goldenfeld M, Levkovitch-Verbin HJ, Melamed S. Donor scleral patch for treating hypotony due to leading and/or overfiltering blebs. J Glaucoma. 2005;14(6):492-6.

4. Kosmin AS, Wishart PK. A full-thickness scleral graft for the surgical management of a late filtration bleb leak. Ophthalmic Surg Lasers. 1997;28(6): 461-8. 
5. Oh JH, Kim, JC. Repair of scleromalacia using preserved scleral graft with amniotic membrane transplantation. Cornea. 2003;22(4):288-93.

6. Kamiya H, Kitajima Y. Successful use of preserved sclera of eyelid reconstruction. Eur J Dermatol. 2003;13(3):267-71.

7. Inkster CF, Ng SG, Leatherbarrow B. Primary banked scleral patch graft in the prevention of exposure of hydroxyapatite orbital implants. Ophthalmology. 2002;109(2):389-92. Comment in: Ophthalmology. 2003;110(7):1281; author reply 1281. Ophthalmology. 2003;110(7):1282; author reply 1282 .

8. Mehta JS, Franks WA. The sclera, the prion, and the ophthalmologist. Br J Ophthalmol. 2002;86(5):587-92. Comment in: Br J Ophthalmol. 2002; 86(12): 1459.

9. Hafeez YM, Zuki AB, Yusof N, Asnah H, Logman MY, Noordin MM, et al Effect of freeze-drying and gamma irradiation on biomechanical properties of bovine pericardium. Cell Tissue Bank. 2005;6(2):85-9.

10. Rey L, May JC. Freeze-Drying/ Liophilization of Pharmaceutical and Biological Products. $2^{\text {nd }}$ ed. New York: Marcel Dekker; 2004.

11. Maizato MJ, Higa OZ, Mathor MB, Camillo MA, Spencer PJ, Pitombo RN, et al. Glutaraldehyde-treated bovine pericardium: effects of lyophilization on cytotoxicity and residual aldehydes. Artif Organs. 2003;27(8):692-4.

12. Han Y, Quan GB, Liu XZ, Ma EP, Liu A, Jin P, et al. Improved preservation of human red blood cells by lyophilization. Cryobiology. 2005;51(2):152-64

13. Harding KG, Krieg T, Eming SA, Flour ML, Jawien A, Cencora A, et al.
Efficacy and safety of the freeze-dried cultured human keratinocyte lysate, LyphoDerm $0.9 \%$, in the treatment of hard-to-heal venous leg ulcers. Wound Repair Regen. 2005;13(2):138-47.

14. Nakamura T, Yoshitani M, Rigby H, Fullwood NJ, Ito W, Inatomi T, et al. Sterilized, freeze-dried amniotic membrane: a useful substrate for ocular surface reconstruction. Invest Ophthalmol Vis Sci. 2004;45(1):93-9.

15. Kirkpatrick BD, Tenney KM, Larsson CJ, O`Neill JP, Ventrone C, Bentley $\mathrm{M}$, et al. The novel oral typhoid vaccine M01ZH09 is well tolerated and highly immunogenic in 2 vaccine presentations. J Infect Dis. 2005;192(3):360-6. Comment in: J Infect Dis. 2005;192(3):357-9.

16. Paufique L. [Technic of intra-scleral compression]. Bibl Ophthalmol. 1965; 65:152-3. French.

17. Spatzener M, Deporter, DA. Preprosthetic alveolar ridge correction using glutaraldehyde cross-linked, lyophilized scleral allografts. Compendium. 1990;11(3):176,178-81.

18. Lormee J, Thomine F, Brion M. [Organic non-mineralized allografts. Lyophilized sclera. Lyophilized dura-mater]. Inf Dent. 1987;69(24):2113-8. French.

19. François J, Verbraeken H, Hanssens M. Scleral pockets and lyophilized sclera in retinal detachments. Ophthalmologica. 1979;179(3):153-7.

20. Liu W, Wang DQ, Nail SL. Freeze-drying of proteins from a sucrose-glycine excipient system: effect of formulation composition on the initial recovery of protein activity. AAPS PharmSciTech. 2005;6(2):E150-7. 